\title{
Evaluation of Genotoxicity of Combined Pollution by Cadmium and Atrazine
}

\author{
A. J. Lin, Y. G. Zhu, Y. P. Tong, C. N. Geng \\ Research Center for Eco-Environmental Sciences, Chinese Academy of Sciences, \\ 18 Shuangqing Road, Haidian, Beijing 100085, People's Republic of China
}

Received: 30 May 2004/Accepted: 9 December 2004

There is a general need for fast, reliable and simple techniques to evaluate the genotoxicity of any chemicals in the environment. In the past the Allium test, chromosome aberration (CA), micronucleus test (MCN), the Ames test have been widely used to evaluate DNA damages induced by different agents, such as heavy metals. However these tests are time-consuming and often expensive. The single cell gel electrophoresis (SCGE), commonly known as comet assay developed by Ostling and Johanson (Rojas et al. 1999), has been used in recent years. The comet assay appears to be a simple and direct, short-term and sensitive genotoxicity test technique to quantitatively detect many kinds of DNA damages in individual eukaryotic cells (Navarrete et al. 1997). The common comet assay was alkaline comet assay introduced by Singh et al. (1988), who used alkaline electrophoresis to analyze DNA damages, this method is capable of detecting DNA single-strand breakages and alkali labile sites in individual cells. In 1996, the first use of this method on plant roots for genotoxicity assessment was reported (Koppen and Verschaeve 1996). Using comet assay, plants could be used for environmental monitoring. It may offer increased sensitivity and greater flexibility for detecting DNA damages than the traditionally used methods, such as CA and MCN tests (Madejón et al. 2001; Jovtchev et al. 2001).

Cadmium ( $\mathrm{Cd}$ ) is a non-essential metal with high toxicity, and it has also been shown to be a potentially genotoxic heavy metal in the environment (Toppi and Gabbrielli et al. 1999). Atrazine (Atr) first introduced in 1958 as a selective preand post-emergence herbicide has been one of the most extensively used herbicides worldwide to control broad-leaved weeds (Ribas et al. 1998). Atrazine has a relative long half-life in the environment and is frequently detected in all environmental compartments, particularly in surface water as a result of run-off following the application to soils (Wenk et al. 1998).

The majority of laboratory experiments on genotoxicity of pollutants have been concentrated on single pollutants, and there have been few reports on the 
genotoxicity of cadmium to plant cells in mixture with pesticides (Martin et al. 1998). This makes it difficult to assess the genotoxicity caused by chemical mixtures, which occur widely in the environment. Moreover, due to the mixture of pollutants normally occurring in the field, studies on single pollutants are often not relevant to the ambient situation. This calls for the investigation of effects caused by mixtures of pollutants. Due to the ubiquity of cadmium contamination in agricultural soils and the wide application of atrazine, in this study, we investigated the genotoxicity on roots of Allium cepa, which is an important vegetable in china even in the world, induced by cadmium and atrazine, individually and in mixture.

\section{MATERIALS AND METHODS}

Atrazine was obtained from Shandong Agricultural University, China and has a purity of over $99 \%$. Normal melting point agarose (NMA), low melting point agarose (LMA), $\mathrm{CdCl}_{2} \cdot 2.5 \mathrm{H}_{2} \mathrm{O}$ and other reagents were purchased from Sigma, USA. $\mathrm{CdCl}_{2} \cdot 2.5 \mathrm{H}_{2} \mathrm{O}$ was dissolved in redistilled water and atrazine was dissolved in acetone at different concentrations.

Seeds of Allium cepa L. (from the Chinese Academy of Agricultural Sciences) were surface sterilized in a $3 \% \mathrm{H}_{2} \mathrm{O}_{2}$ solution, the seeds were then thoroughly rinsed with distilled water and then soaked in distilled water at $25{ }^{\circ} \mathrm{C}$ for $12 \mathrm{~h}$. Seeds were germinated on moist filter paper in an incubator at $25{ }^{\circ} \mathrm{C}$. When the roots were $2-3 \mathrm{~cm}$ long, they were used in the following experiments.

In solution treatments the roots were treated in solutions $(50 \mathrm{ml}$ in beakers) containing different combination of $\mathrm{Cd}$ and atrazine for $2 \mathrm{~h}$ in darkness at $25^{\circ} \mathrm{C}$. In $\mathrm{Cd}$ treatments, the intact roots were treated in solutions containing $0,0.05,0.20$ $\mathrm{mg} \mathrm{L}^{-1} \mathrm{Cd}^{2+}$ with or without $5.0 \mathrm{mg} \mathrm{L}^{-1}$ atrazine. In atrazine treatments, the intact roots were treated in solutions containing $0,5.0,20.0 \mathrm{mg} \mathrm{L}^{-1}$ atrazine with or without $0.05 \mathrm{mg} \mathrm{L}^{-1} \mathrm{Cd}^{2+}$. Each treatment was repeated 3 times.

In soil treatments the soil collected from Jiaxing, Zhejiang Province in Southeast China was used. The soil has been used for vegetables production for more than 5 years, and has been subjected to minimum $\mathrm{Cd}$ contamination and with no atrazine application history. Soil sample was passed through a $1-\mathrm{mm}$ sieve and stored at $4^{\circ} \mathrm{C}$ before use. $150 \mathrm{~g}$ air-dried soil was used in each soil treatment. In $\mathrm{Cd}$ treatments, $\mathrm{Cd}$ was added to the soil by adding $\mathrm{Cd}$ stock solutions to the soils to give the $\mathrm{Cd}$ concentrations of $0.0,0.2,0.5 \mathrm{mg} \mathrm{kg}^{-1}$ air-dried soil with or without 5 $\mathrm{mg} \mathrm{kg}^{-1}$ atrazine. In atrazine treatments, atrazine was added to the soil by adding atrazine acetone stock solutions to the soils to give the atrazine concentrations of $0.0,5,20 \mathrm{mg} \mathrm{kg}^{-1}$ air-dried soil with or without $0.5 \mathrm{mg} \mathrm{kg}^{-1} \mathrm{Cd}$. The soil was thoroughly mixed and allowed to be air dried to remove the acetone. After 
adjusted to moisture content of $20 \%$ (w/w) using distilled water, the soil was filled into plastic containers and each experiment was repeated 3 times. The soils were incubated at $25^{\circ} \mathrm{C}$ and the distilled water was regularly added to keep the moisture content of $20 \%$. After being incubated for 1 week the intact roots were treated in these soils for $2 \mathrm{hr}$.

The protocols of comet assay were provided by Dr. T Gichner (Institute of Experimental Botany, Academy of Sciences of the Czech Republic, La Karlovce 1a, 16000 Prague 6, Czech Republic). All operations were conducted under dim or yellow light to avoid DNA damages by light. After exposure to various treatments, roots were washed 3 times with double-distilled water and blotted dry with a filter paper. They were placed on ice for $2 \mathrm{~min}$ to keep them turgid. They were then placed in a $60 \mathrm{~mm}$ petri dish on ice and covered with $250 \mu \mathrm{l}$ of cold $1 \times$ PBS $\left(\mathrm{NaCl} 130 \mathrm{mM}, \mathrm{Na}_{2} \mathrm{HPO}_{4} 7 \mathrm{mM}, \mathrm{NaH}_{2} \mathrm{PO}_{4} 3 \mathrm{mM}\right.$, EDTA 50mM, pH 7.5). Using a new razor blade, each root was gently cut into pieces. The pieces were washed in the buffer by repeated pipetting using a micropipette.

The nuclei suspension was used in the alkaline comet assay, as described by Gichner and Navarrete with some modifications (Navarrete et al. 1997; Gichner et al. 2000). After the preparation of slides they were put in freshly prepared cold alkaline buffer $\left(300 \mathrm{mM} \mathrm{NaOH}, 1 \mathrm{mM} \mathrm{Na} \mathrm{E}_{2}\right.$ EDT, $\left.\mathrm{pH}>13\right)$ at $4{ }^{\circ} \mathrm{C}$ to allow the DNA to denature. Electrophoresis was then conducted at $4{ }^{\circ} \mathrm{C}$ for $15 \mathrm{~min}$ at 300 $\mathrm{mA}$. After electrophoresis the slides were neutralized with a neutralization buffer $\left(0.4 \mathrm{~mol} \mathrm{~L}^{-1}\right.$ Tris- $\left.\mathrm{HCl}, \mathrm{pH} 7.5\right)$ at room temperature for $15 \mathrm{~min}$.

Each slide was stained with $50 \mu 1$ of $13 \mathrm{mg} \cdot \mathrm{L}^{-1}$ ethidium bromide and viewed with a Nikon fluorescent microscope (DIAPHOT 300, Japan) with an excitation filter of 510-560 nm and a barrier of $590 \mathrm{~nm}$. The stained DNA gives a red emission. Images of the comets were captured by a Nikon Coolpix 4500 digital camera. For each slide 50 randomly chosen cells were analyzed.

An image analysis system, CASP, developed by Wojcik was employed to measure various comet parameters (Wojcik et al. 2003). In the assay the tail length, tail DNA, tail moment(TM) and Olive tail moment (OTM) were measured as the parameters. The tail length is the relative tail length as a rough estimate of the DNA migration was recorded in arbitrary units. Tail DNA means relative \% of DNA in the comet tail. TM is integrated value of DNA density multiplied by the migration distance. OTM is the product of the distance (in x direction) between the center of gravity of the head and the center of gravity of the tail and percent tail DNA. Analyses of variance were performed on the data using window-based Genestat (NAG Ltd., England). 
Parameters of genotoxicity, tail length, tailDNA, TM and OTM of Cd treatment and the mixture of $\mathrm{Cd}$ and atrazine treatment in solution are shown in Table 1. It was apparent that with increasing $\mathrm{Cd}$ concentrations in the solutions, the DNA damages increased significantly $(\mathrm{P}<0.01)$, which indicated that $\mathrm{Cd}$ induced DNA damages to root cells of Allium cepa $\mathrm{L}$., and a linear dose-response curve between Cd concentrations and DNA damages was observed. Cd was found to produce oxidative stress, which induced DNA damages (Toppi and Gabbrielli 1999). Various papers have reported the genotoxicity of $\mathrm{Cd}$ and these results were similar to those from our experiments. Using the neutral red incorporation test the genotoxicity of $\mathrm{Cd}$ has been studied on isolated cells of Mercenaria mercenaria showing that the cytotoxic effect of $\mathrm{Cd}$ was dose-dependent at concentrations much higher $\left(0.5-1.5 \times 10^{-3} \mathrm{M}\right)$ than those used in our experiments $(0.45-1.8 \times$ $10^{-6} \mathrm{M}$ ) (Pennec and Pennec 2001). It was found that $\mathrm{Cd}$ had an impact on Mercenaria mercenaria at young growth stage, probably because of its capacity to inhibit the RNA action of polymerase (Hidalgo et al. 1976). With the addition of 5 $\mathrm{mgL}^{-1}$ atrazine the values of tail length, tailDNA, TM and OTM decreased compared to those without atrazine, which indicated that the DNA damages induced by the mixture of $\mathrm{Cd}$ and atrazine was significantly lower than that induced by $\mathrm{Cd}$ singly at all $\mathrm{Cd}$ concentrations $(\mathrm{P}<0.01)$.

Table 1. Parameters of DNA damages induced by $\mathrm{Cd}$ and $\mathrm{Cd}+$ Atr in solution $\pm \mathrm{SE}$.

\begin{tabular}{cccccc}
\hline \multirow{2}{*}{ dd* $^{*}$} & \multirow{2}{*}{ Atr* } & \multicolumn{5}{c}{ Parameters of DNA damages } \\
\cline { 3 - 6 } 0.00 & 0 & Tail length & Tail DNA (\%) & TM & OTM \\
0.05 & 0 & $43.39 \pm 1.60$ & $53.75 \pm 1.81$ & $23.81 \pm 1.17$ & $14.00 \pm 0.43$ \\
0.20 & 0 & $55.54 \pm 3.42$ & $67.19 \pm 1.80$ & $37.77 \pm 3.05$ & $19.80 \pm 1.22$ \\
0.00 & 5 & $30.30 \pm 0.99$ & $44.26 \pm 0.25$ & $15.54 \pm 0.21$ & $9.79 \pm 0.27$ \\
0.05 & 5 & $33.79 \pm 1.28$ & $53.97 \pm 4.23$ & $18.73 \pm 1.14$ & $10.70 \pm 0.48$ \\
0.20 & 5 & $34.80 \pm 3.10$ & $57.27 \pm 2.78$ & $20.57 \pm 2.40$ & $11.82 \pm 0.78$ \\
\hline $\mathrm{mg} \mathrm{L}^{-1}$ & & & & &
\end{tabular}

Table 2. Parameters of DNA damages induced by $\mathrm{Cd}$ and $\mathrm{Cd}+\mathrm{Atr}$ in soil $\pm \mathrm{SE}$.

\begin{tabular}{cccccc}
\hline \multirow{2}{*}{ Cd } & Atr & \multicolumn{5}{c}{ Parameters of DNA damages } \\
\cline { 3 - 6 } 0.00 & 0 & Tail length & Tail DNA (\%) & TM & OTM \\
0.20 & 0 & $30.30 \pm 0.64$ & $34.47 \pm 2.38$ & $8.59 \pm 0.72$ & $5.82 \pm 0.76$ \\
0.50 & 0 & $37.56 \pm 4.31$ & $52.28 \pm 4.62$ & $20.79 \pm 4.59$ & $12.19 \pm 1.81$ \\
0.00 & 5 & $38.00 \pm 2.88$ & $51.74 \pm 0.88$ & $20.72 \pm 1.86$ & $12.44 \pm 0.98$ \\
0.20 & 5 & $34.32 \pm 3.05$ & $48.56 \pm 6.68$ & $18.21 \pm 3.51$ & $10.71 \pm 1.59$ \\
0.50 & 5 & $45.59 \pm 2.50$ & $57.33 \pm 3.44$ & $26.54 \pm 1.88$ & $14.51 \pm 0.79$ \\
\hline
\end{tabular}


DNA damages induced by $\mathrm{Cd}$ and $\mathrm{Cd}+$ atrazine in soil are shown in Table 2 , and it could be found that with increasing $\mathrm{Cd}$ concentrations the values of tailDNA, TM and OTM increased significantly $(\mathrm{P}<0.05)$ especially the value of tail length $(\mathrm{P}<0.01)$. It was found that $\mathrm{Cd}$ induced less DNA damages in soil than in solution treatment. The addition of atrazine to soil had no obvious effect on the genotoxicity of $\mathrm{Cd}$.

DNA damages induced by atrazine and the mixture of atrazine with $0.5 \mathrm{mgL}^{-1} \mathrm{Cd}$ to the root cells of Allium cepa $L$. in solution and in soil are shown in Tables 3 and 4. Compared to the control, all the atrazine treatments resulted in DNA damages $(\mathrm{P}<0.05)$, and there was a dose-dependent relationship. The genotoxicity of the mixture of $\mathrm{Cd}$ and atrazine differed from that of the atrazine singly. With the absence of atrazine in the solution, DNA damages were induced by $\mathrm{Cd}$ at $0.05 \mathrm{mg}$ $\mathrm{L}^{-1}(\mathrm{P}<0.01)$. At the atrazine concentration of $5.0 \mathrm{mgL}^{-1}$ the genotoxicity of the mixture was similar to that of atrazine alone. At the atrazine concentration of 20.0 $\mathrm{mg} \mathrm{L}^{-1}$ the addition of Cd significantly decreased DNA damages $(\mathrm{P}<0.05)$.

Table 3. Parameters of DNA damages induced by Atr and Atr $+\mathrm{Cd}$ in solution $\pm \mathrm{SE}$.

\begin{tabular}{cccccc}
\hline \multirow{2}{*}{ Atr } & Cd & \multicolumn{5}{c}{ Parameters of DNA damages } \\
\cline { 3 - 6 } 0.0 & 0 & Tail length & Tail DNA (\%) & TM & OTM \\
5.0 & 0 & $31.13 \pm 0.43$ & $49.57 \pm 1.08$ & $16.05 \pm 0.29$ & $9.59 \pm 0.15$ \\
20.0 & 0 & $36.54 \pm 2.24$ & $55.01 \pm 1.49$ & $20.30 \pm 1.16$ & $11.50 \pm 0.68$ \\
0.0 & 0.05 & $34.23 \pm 1.84$ & $52.41 \pm 0.40$ & $18.40 \pm 0.95$ & $11.24 \pm 0.55$ \\
5.0 & 0.05 & $31.73 \pm 3.31$ & $50.66 \pm 2.34$ & $16.86 \pm 2.32$ & $10.26 \pm 1.02$ \\
20.0 & 0.05 & $25.70 \pm 1.29$ & $45.56 \pm 4.14$ & $12.38 \pm 1.52$ & $8.48 \pm 0.79$ \\
\hline
\end{tabular}

The toxicity of atrazine has been demonstrated since the 1970s in various organisms. Studies assessing the genotoxic potential of atrazine have in the past been inconclusive. There have been some reports showing an unconfirmed tendency that atrazine was genotoxic. In the study by Pennec, the digestive gland of bivalve molluscs was used as a model to examine the genotoxic effects of atrazine, and results showed that at the concentration of $1 \times 10^{-5} \mathrm{M}$ atrazine might be genotoxic (Pennec and Pennec 2001). Using techniques, such as sister-chromatid exchanges (SCE), CA and MCN, Riba et al (1998) demonstrated that atrazine was able to exert a weak cytotoxic effect (Ribas et al. 1998). Using very high concentrations of atrazine $\left(125-500 \mathrm{mg} \mathrm{kg}^{-1}\right)$, a weak genotoxic effect was observed for mice blood cells (Tennant et al. 2001). Several studies have reported that atrazine at agricultural concentrations can induce genotoxicity to plants (Plewa et al. 2000). Mohammed et al. (1999) employed the Trad-MCN test to evaluate genotoxicity, and results showed positive effects at a dose of 10-50 mg $\mathrm{L}^{-1}$ (Mohammed and Ma 1999). Our finding were similar to those based on 
Table 4. Parameters of DNA damages induced by Atr and Atr $+\mathrm{Cd}$ in soil $\pm \mathrm{SE}$.

\begin{tabular}{cccccc}
\hline \multirow{2}{*}{ Atr } & Cd & \multicolumn{5}{c}{ Parameters of DNA damages } \\
\cline { 3 - 6 } & & Tail length & Tail DNA (\%) & TM & OTM \\
0.0 & 0 & $25.75 \pm 1.60$ & $35.05 \pm 2.77$ & $10.21 \pm 1.51$ & $7.47 \pm 1.07$ \\
5.0 & 0 & $25.88 \pm 1.07$ & $35.59 \pm 0.30$ & $10.09 \pm 0.77$ & $6.96 \pm 0.36$ \\
20.0 & 0 & $32.16 \pm 1.91$ & $48.07 \pm 3.91$ & $16.44 \pm 2.03$ & $9.97 \pm 0.66$ \\
0.0 & 0.5 & $43.41 \pm 2.02$ & $43.68 \pm 1.90$ & $20.56 \pm 1.52$ & $10.98 \pm 0.80$ \\
5.0 & 0.5 & $32.21 \pm 2.20$ & $48.95 \pm 3.17$ & $16.54 \pm 1.43$ & $10.45 \pm 0.57$ \\
20.0 & 0.5 & $37.78 \pm 2.97$ & $53.79 \pm 2.82$ & $20.77 \pm 0.57$ & $12.91 \pm 0.50$ \\
\hline
\end{tabular}

There is little information available in the literature on the interactions between pesticides and $\mathrm{Cd}$, or other metals. Stec (2000) observed that $\mathrm{Mg}$ restored the DNA repair inhibition caused by $\mathrm{Cd}$ in sheep lymphocytes. In a study by Institoris (2002) the interactions between $\mathrm{Cd}$ and propoxur ( $\mathrm{Pr}$, a carbarmate pesticide), was investigated. $\mathrm{Cd}$ and $\mathrm{Pr}$ induced damages to rat individually and a significant interaction between $\mathrm{Cd}$ and $\mathrm{Pr}$ was detected by some parameters (Institoris et al. 2002). Our results suggested that the interactions between $\mathrm{Cd}$ and atrazine might reduce the genotoxicity of $\mathrm{Cd}$ as single pollutant. The genotoxicity of the mixture of Cd at different concentrations in solution with $5 \mathrm{mgL}^{-1}$ atrazine was lower than that with $\mathrm{Cd}$ only, but higher than that of $5 \mathrm{mgL}^{-1}$ atrazine alone. The inhibitory effect of atrazine on Cd genotoxicity to the roots of Allium cepa L may be partly due to the complexation between $\mathrm{Cd}$ and atrazine. In a synergistic extraction study (Martin et al.1998), it was shown that atrazine could enhance the extraction of various metals including $\mathrm{Cd}$, and the enhancement was the highest for $\mathrm{Cd}$ compared to $\mathrm{Zn}$ and $\mathrm{Cu}$ through the formation of a $\mathrm{ML}_{2}$ (ATR) complex (Martin et al.1998). The efficient complexation between atrazine and $\mathrm{Cd}$ could be explained by the "hard-soft theory" that the "soft" nitrogen atoms of atrazine have strong interactions with "soft" cations such as Cd (Martin et al.1998). However, it is interesting to note that the genotoxicity of atrazine at the concentration of $20 \mathrm{mg}$ $\mathrm{L}^{-1}$ was significantly reduced by the addition of $\mathrm{Cd}$ at concentration of $0.05 \mathrm{mg}$ $\mathrm{L}^{-1}$. This could not be fully explained by the complexation between $\mathrm{Cd}$ and atrazine, since the concentration of atrazine in the solution $\left(20 \mathrm{mg} \mathrm{L}^{-1}\right)$ was much higher than that of $\mathrm{Cd}\left(0.05 \mathrm{mg} \mathrm{L}^{-1}\right)$. Further investigation is therefore warranted to elucidate the mechanisms of the toxicity of the mixture of $\mathrm{Cd}$ and atrazine to plant roots.

It was found that in soil experiment the interaction between $\mathrm{Cd}$ and atrazine was not obvious, which could be due to the fact that in soil $\mathrm{Cd}$ could combine to soil organic matter. It has been demonstrated that over $60 \%$ of soil solution $\mathrm{Cd}$ might be present in association with dissolved organic matter (Vig et al. 2003). Thus, in 
soil treatment the lack of interactions were partly because the soil is a complex system and the chance of complexation between atrazine and $\mathrm{Cd}$ was low.

In conclusion, the fact that the current experiments were performed on isolated nuclei and the treatment time was only $2 \mathrm{~h}$ suggested that the method is a fast and simple for genotoxicity studies on soil contamination. Results obtained from the current study confirmed that $\mathrm{Cd}$ and atrazine were genotoxic and the interaction between C.d and atrazine decreased the genoxicity compared to the situation when the two contaminants are present singly. The antagonistic interactions between $\mathrm{Cd}$ and atrazine might be due to the formation of $\mathrm{Cd}-\Lambda$ trazine complex.

Acknowledgments This rescarch was supported by the Ministry of Science and Technology (2002CB410808) and the Chinese Academy of Sciences (K7CX1-SW-19). We want to thank Professor Nigel Bell from Imperial College for his critical comments and editing the English.

\section{REFERENCES}

Gichner T, Ptacekk O, Stavreva DA, Wagner ED, Plewa MJ (2000) A comparison of DNA repair using the comet assay in tobacco seedlings after exposure to alkylating agents or ionizing radiation. Mut Res 470: $1-9$

Hidalgo HA, Koppa V, Bryan SE (1976) Effect of cadmium on RNA-polymerase and protein synthesis in rat liver, FEBS Lett 64:159-162

Institoris L, Papp A, Siroki O, Banerjee BD, Desi I (2002) Immuno- and neurotoxicological investigation of combined subacute exposure with the carbamate pesticide propoxur and cadmium in rats. Toxicology 178: 16I-173

Jovtchev G, Menke M, Schubert I (200I) The comet assay detects adaptation to MNU-induced DNA damage in barley. Mut Res 493: 95-100

Konca K, Lankoff A, Banasik A, Lisowska H, Kuszewski T, Gozdz S, Koza Z, Wojcik A (2003) A cross-platform public domain PC image-analysis program for the comet assay. Mut Res. 534: 15-20

Koppen G, Verschaeve L (1996) The alkaline comet test on plant cells: A new genotoxicity test for DNA strand breaks in Vicia faba root cell. Mut Res 360: 193-200

Martin M, Hagege A, Brunette JP, Leroy M (1998) Use of synergistic extraction for the study of atrazine/metal interactions. Anal Chimica Acta 373: 161-165

Mohammed KB, Ma TH (1999) Tradescantia-micronucleus and -stamen hair mutation assays on genotoxicity of the gaseous and liquid forms of pesticides. Mut Res 426: 193-199

Navarrete $\mathrm{MH}$, Carrera P, Miguel M, Torre C (1997) A fast comet assay variant for solid tissue cells. The assessment of DNA damage in higher plants. Mut Res 389: 271-277

Pennec GL, Pennec ML (2001) Evaluation of the toxicity of chemical compounds 
using digestive acini of the bivalve mollusc Pecten maximus $L$. maintained alive in vitro. Aquat Toxicol 53:1-7

Plewa MJ, Kargalioglu Y, Vankerk D, Mincar RA, Wagner ED (2000) Development of quantitative comparative cytotoxiciy and genotoxicity assays for environmental hazardous chemicals. Water Sci Technol 42: 109-116

Ribas G, Surralles J, Carbonell L, Creus A, Xamena N, Marcos R (1998) Lack of genotoxicity of the herbicide atrazine in cultured human lymphocytes, Mut Res 416: 93-99

Rojas E, Lopez MC, Valverde M (1999) Single cell gel electrophoresis assay: methodology and applications. J Chromatog 722: 225-254

Singh NP, McCoy MT, Tice RR, Schneider EL (1988) A simple technique for quantitation of low levels of DNA damage in individual cells. Exp Cell Res 175: 184-19]

Stec J (2000) Inhibition of DNA repair by cadmium and lead in sheep lymphocytes: protective interaction of magnesium. Bull vet Inst Pulawy 44: 221-226

Tennant AH, Peng B, Kligerman AD (2001) Genotoxicity studies of three triazine herbicides: in vivo studies using the alkaline single cell gel (SCG) assay. Mut Res 493: 1-10

Toppi LS, Gabbrielli R (1999) Response to cadmium in higher plants. Environ Lxp Botany 41: 105-130

Vig K, Megharaj M, Sethunathan N, Naidu R (2003) Bioavailability and toxicity of cadmium to microorganisms and their activities in soil: a review. Adv Environ Res 8: 121-135

Wenk M, Baumgartner T, Dobovsek J, Fuchs T, Kucsera J, Zopli J, Stucki G (1998) Rapid atrazine mineralisation in soil slurry and moist soil by inoculation of an atrazine-degrading Pseudomonassp. Strain. Appl Microbiol Biotechnol 49: 624-630 